\title{
Phase I-II study of plitidepsin and dacarbazine as first-line therapy for advanced melanoma
}

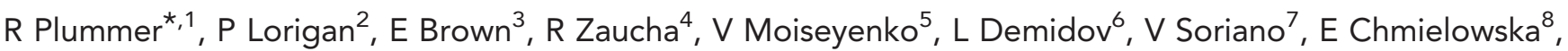 \\ R Andrés ${ }^{9}$, G Kudryavtseva ${ }^{10}$, C Kahatt $^{11}$, S Szyldergemajn ${ }^{11}$, S Extremera ${ }^{11}$, B de Miguel ${ }^{11}$, M Cullell-Young ${ }^{11}$ \\ and $\mathrm{H}_{\text {Calvert }}{ }^{1}$

\begin{abstract}
${ }^{1}$ Northern Centre for Cancer Care, Freeman Hospital, Newcastle upon Tyne, NE7 7DN, UK; ${ }^{2}$ Christie Hospital, Manchester, UK; ${ }^{3}$ Western General Hospital, Edinburgh, UK; ${ }^{4}$ UCK, Medical University of Gdansk, Poland; ${ }^{5}$ Petrov Research Institute of Oncology, Saint Petersburg, Russia; ${ }^{6}$ Russian Cancer Research Center, Moscow, Russia; ${ }^{7}$ Instituto Valenciano de Oncología, Valencia, Spain; ${ }^{8}$ Centrum Onkologii Prof. F. Lukaszczyka, Bydgoszcz, Poland; ${ }^{9}$ Hospital Clínico Lozano Blesa, Zaragoza, Spain; ${ }^{10}$ Medical Radiological Research Center, Obninsk, Russia and ${ }^{11}$ Pharma Mar, S.A., Colmenar Viejo, Madrid, Spain
\end{abstract}

Background: This phase I-II trial compared plitidepsin 1-h infusion alone or combined with dacarbazine (DTIC) 1-h infusion as front-line therapy for advanced melanoma.

Methods: The recommended dose (RD) for plitidepsin/DTIC was defined in the first stage. In the second stage, patients were randomised to receive single-agent plitidepsin $3.2 \mathrm{mg} \mathrm{m}^{-2}(n=20)$ on days 1,8 and 15 every 4 weeks (q4wk) or plitidepsin $2.4 \mathrm{mg} \mathrm{m}^{-2}$ on days 1,8 and $15 \mathrm{q} 4 \mathrm{wk}$ combined with DTIC $800 \mathrm{mg} \mathrm{m}^{-2} \mathrm{q} 4 \mathrm{wk}(n=38)$.

Results: The overall response rate with plitidepsin/DTIC was 21.4\%; all responders had normal serum lactate dehydrogenase (LDH) levels and performance status $\leqslant 1$ at baseline. Median progression-free survival (PFS) with plitidepsin/DTIC was 3.3 months in all patients, and 4.3 months in those with baseline normal LDH. No responses occurred with single-agent plitidepsin and median PFS was 1.5 months. Both regimens were well tolerated. Haematological abnormalities were more common and transaminase increases more severe with plitidepsin/DTIC. Treatment-related transaminase increases leading to infusion omission on day 8 were relatively common. No drug-drug pharmacokinetic interactions were found.

Conclusion: This plitidepsin/DTIC schedule has antitumour activity and manageable toxicity in advanced melanoma. Further evaluation of plitidepsin $2.4 \mathrm{mg} \mathrm{m}^{-2}$ fortnightly and DTIC $800 \mathrm{mg} \mathrm{m}^{-2} \mathrm{q} 4 \mathrm{wk}$ is recommended.

Dacarbazine (DTIC) was the mainstay of treatment for metastatic melanoma until the recent approval (in 2011) of the anticytotoxic T-lymphocyte antigen-4 (CTLA-4) monoclonal antibody ipilimu$\mathrm{mab}$ and the B-raf protein inhibitor vemurafenib. Responses to single-agent DTIC were generally short lived and occurred in 6-15\% of patients (Falkson et al, 1998; Chapman et al, 1999; Chiarion Sileni et al, 2001; Avril et al, 2004; Bedikian et al, 2006; Schadendorf et al, 2006; Patel et al, 2011). Combinations of DTIC and other cytotoxic drugs increased response rates, but had no significant effects on survival and were associated with greater toxicity (Agarwala, 2009; Mouawad et al, 2010). Antitumour activity was found for DTIC-based chemotherapy combined with the anti-vascular endothelial growth factor (VEGF) monoclonal antibody bevacizumab, but these results were preliminary and required confirmation in randomised trials (Munzone et al, 2007).

Plitidepsin is a cyclic depsipeptide originally isolated from the Mediterranean tunicate Aplidium albicans and currently produced by chemical synthesis. It has in vitro activity against a wide range of 
human malignant cell lines, including melanoma. Plitidepsin triggers apoptosis in vitro and blocks VEGF secretion in different tumour models. The finding that DTIC increases protein expression of VEGF and promotes tumour growth and metastasis in vivo in human melanoma cells (Lev et al, 2003, 2004) suggested that a combination of plitidepsin and DTIC might have synergistic antineoplastic effects in metastatic melanoma. Plitidepsin showed sustained clinical antitumour activity in a melanoma patient in a phase I study (Anthoney et al, 2000). In a phase II trial, plitidepsin 3-h intravenous (i.v.) infusion administered fortnightly as secondline therapy induced durable partial response (PR) in 5\% of 35 patients with unresectable melanoma resistant to prior DTICbased chemotherapy (Eisen et al, 2009).

This open-label clinical trial was divided into two stages. The first stage was a nonrandomised, dose-finding, phase I study that evaluated the maximum tolerated dose (MTD) and the recommended dose $(\mathrm{RD})$ of plitidepsin (1-h infusion on days 1,8 , and 15) combined with DTIC (1-h infusion on day 1 ) every 4 weeks $(\mathrm{q} 4 \mathrm{wk})$ as front-line treatment for unresectable advanced melanoma. This weekly plitidepsin schedule was chosen over the fortnightly schedule to explore whether more frequent drug infusions would result in less toxicity and an enhanced efficacy by giving a greater dose density. The DTIC schedule was selected to accommodate to the weekly plitidepsin schedule and to provide the patients with a resting week for the recovery of laboratory parameters. The second stage was a randomised, two-arm, phase II study that assessed the efficacy of plitidepsin $3.2 \mathrm{mg} \mathrm{m}^{-2}$ as $1-\mathrm{h}$ infusion (on days 1, 8, and 15) q4wk, and of plitidepsin/DTIC combination at the $\mathrm{RD}$ determined in the first stage. The safety profile and pharmacokinetics $(\mathrm{PK})$ of the study regimens were also assessed.

\section{MATERIALS AND METHODS}

Consenting adult patients were recruited between January 2006 and June 2009 at 12 European centres according to Good Clinical Practice requirements, the Declaration of Helsinki and local regulations. Patients were followed up until September 2010. The protocol was approved by the Clinical Research Ethics Committee of each centre. A signed written informed consent was obtained for each patient before any study procedure was done.

Eligibility criteria. The study enrolled previously untreated adult patients with advanced malignant melanoma (adjuvant therapy was allowed if they had recovered from any toxicity); Eastern Cooperative Oncology Group performance status (ECOG PS) $\leqslant 2$; left ventricular ejection fraction (LVEF) within normal limits; and adequate organ function: platelet count $\geqslant 100 \times 10^{9}$ per 1 ; haemoglobin $>9.5 \mathrm{~g} \mathrm{dl}^{-1}$; absolute neutrophil count (ANC) $\geqslant 1.5 \times 10^{9}$ per 1 ; aspartate aminotransferase (AST), alanine aminotransferase (ALT) and alkaline phosphatase (AP) $\leqslant 2.5 \times$ upper limit of normal (ULN); total bilirubin $\leqslant 1.5 \times$ ULN; creatinine clearance $\geqslant 40 \mathrm{ml} \mathrm{min}{ }^{-1}$ or creatinine $\leqslant 1.4 \mathrm{mg} \mathrm{dl}^{-1}$; creatine phosphokinase $(\mathrm{CPK}) \leqslant 2.5 \times \mathrm{ULN}$; and albumin $\geqslant 2.5 \mathrm{~g} \mathrm{dl}^{-1}$.

Patients were excluded if they had received any prior systemic therapy for metastatic melanoma; if they were relapsing/progressing within 6 months after adjuvant or neoadjuvant therapy for nonmetastatic melanoma; if they had locoregional melanoma relapsing or progressing after locoregional drug therapy; if surgery would result in cure or significant palliation; if treated with any locoregional or adjuvant investigational product within 30 days before inclusion, with radiotherapy within 4 weeks before inclusion ( 6 weeks in case of extensive radiotherapy); if they had any major illness incompatible with the protocol; if they were immunocompromised; or if they had a history of significant neurological or psychiatric disorders, or hypersensitivity to any component of the study drug(s).

Study treatment and dose escalation. Study treatment during the first stage consisted of plitidepsin (PharmaMar, Colmenar Viejo, Madrid, Spain) administered as a 1-h i.v. infusion on days 1, 8 and 15 , followed by DTIC as a 1-h i.v. infusion on day 1 , in cycles of 4 weeks. The starting plitidepsin dose $\left(1.8 \mathrm{mg} \mathrm{m}^{-2}\right)$ was $58 \%$ of its single-agent $\mathrm{RD}, 3.2 \mathrm{mg} \mathrm{m}^{-2}$ (Izquierdo et al, 2008). The starting DTIC dose $\left(800 \mathrm{mg} \mathrm{m}^{-2}\right)$ was $\sim 60 \%$ of the RD intensity $\left(1000 \mathrm{mg} \mathrm{m}^{-2} \mathrm{q} 3 \mathrm{wk}\right)$ for single-agent DTIC when adapted to a q4wk schedule (Eggermont and Kirkwood, 2004).

Dose escalation during the first stage is summarised in Table 1. A standard dose-escalation design for conventional cytotoxic agents was used, with cohorts of 3-6 patients treated at each dose level. Dose-limiting toxicities (DLTs) were evaluated during cycle 1 and were defined as follows: ANC $<0.5 \times 10^{9}$ per 1 for $>5$ days; grade 3 neutropenia with fever $\left(\geqslant 38.5^{\circ} \mathrm{C}\right)$, sepsis or other severe infection; platelet count $<25.0 \times 10^{9}$ per 1 ; any other grade $3 / 4$ nonhaematological adverse event (AE) suspected to be treatment related (except for nausea/vomiting without an optimal antiemetic regimen, hypersensitivity reactions and nonclinically relevant biochemical abnormalities); and any delays in the administration of a subsequent plitidepsin dose exceeding 2 weeks, or omissions of the infusions scheduled on days 8 and 15 because of treatmentrelated AEs. The MTD was defined as the dose level at which at least 2 patients had DLTs, and the RD was defined as the highest dose level at which less than one-third of patients experienced DLTs.

\section{Table 1. Dose escalation, distribution of patients, treatment cycles and dose-limiting toxicities during the phase I stage}

\begin{tabular}{|c|c|c|c|c|c|}
\hline $\begin{array}{l}\text { Dose } \\
\text { level }\end{array}$ & $\begin{array}{c}\text { Plitidepsin/DTIC } \\
\text { dose }\left(\mathrm{mg} \mathrm{m}^{-2}\right)\end{array}$ & $\begin{array}{l}\text { No. of } \\
\text { patients } \\
\text { treated }\end{array}$ & $\begin{array}{l}\text { No. of cycles } \\
\text { administered }\end{array}$ & $\begin{array}{l}\text { No. of patients with DLTs/no. of } \\
\text { patients evaluable for DLTs }{ }^{a}\end{array}$ & Description of DLTs \\
\hline 1 & $1.8 / 800$ & 7 & 25 & $1 / 6$ & Grade 3 ALT increase \\
\hline 2 & $2.4 / 800$ (RD) & 8 & 20 & $1 / 5$ & Grade 3 ALT increase \\
\hline 3 & $3.0 / 800$ & 8 & 23 & $0 / 6$ & - \\
\hline 4 & 2.4/1000 (MTD) & 5 & 8 & $2 / 4$ & $\begin{array}{l}\text { Grade } 3 \text { ALT increase } \\
\text { Grade } 4 \text { febrile neutropenia and } \\
\text { grade } 4 \text { pancytopeniab }\end{array}$ \\
\hline $\begin{array}{l}\text { Abbrev } \\
{ }^{\mathrm{a}} \text { Overa } \\
\text { confou } \\
\mathbf{b}_{\text {This e }}\end{array}$ & $\begin{array}{l}\text { tors }(n=2) \text {, a wrong } \\
\text { f grade } 4 \text { pancytopen }\end{array}$ & ed of grac & $\begin{array}{l}\text { na }(n=1) \text { or hav } \\
\text { nia, grade } 4 \text { ne }\end{array}$ & $\begin{array}{l}\text { narrow sensitivity to DTIC }(n=1) \text {. } \\
\text { and grade } 4 \text { thrombocytopenia. }\end{array}$ & ompleting cycle $1(n=3)$, the presence o \\
\hline
\end{tabular}


During the second stage, eligible patients were randomised without stratification to receive either single-agent plitidepsin $3.2 \mathrm{mg} \mathrm{m}^{-2}$ as 1 -h infusion on days 1,8 and $15 \mathrm{q} 4 \mathrm{wk}$, or plitidepsin/DTIC at the RD previously determined in the first stage. A two-stage Simon design was used in this stage. An interim analysis was conducted once 17 evaluable patients had been included in each arm. If two or more responses were observed in an arm, additional patients were recruited in that arm to a total of 30 evaluable patients. Standard prophylaxis with antihistaminics, steroids and $5-\mathrm{HT}_{3}$ antagonists was made compulsory during dose escalation after some patients had to discontinue treatment because of severe hypersensitivity reactions (possibly linked to the Cremophor oil (Duchefa Farma, Haarlem, Nederland) in the plitidepsin formulation).

Regardless of stage, patients continued receiving treatment as long as they did not experience disease progression or unacceptable toxicity and they had recovered from any previous toxicity. Treatment was interrupted in the event of unacceptable toxicity, and was resumed at the next lowest dose level upon recovery to appropriate values. Treatment on day 1 was delayed for a maximum of 2 weeks to allow recovery from toxicity, but on days 8 and 15 the dose was skipped if the retreatment criteria were not met. Up to two dose reductions were allowed, if necessary.

Patients were evaluable for safety if they had received at least one plitidepsin infusion, and for efficacy if they had received at least two plitidepsin infusions and had undergone disease assessment over $\geqslant 8$ weeks after treatment onset. Patients with early disease progression who died of progression before response evaluation or who stopped treatment because of unmanageable toxicity were also evaluable for efficacy. All toxicities were graded following the National Cancer Institute Common Terminology Criteria for Adverse Events (NCI-CTCAE, v.3.0). Clinical and/or radiological assessments of the tumour according to the Response Evaluation Criteria In Solid Tumours (RECIST, v.1.0) (Therasse et al, 2000) were done every 8 weeks.

PK analyses. Blood samples $(10 \mathrm{ml})$ for PK evaluation were collected during both stages from a peripheral vein of the arm not receiving the first study drug infusion at predefined times, ranging from before infusion onset to up to $168 \mathrm{~h}$ after its end. A whole blood aliquot of $3 \mathrm{ml}$ was separated from each sample and stored at $-20{ }^{\circ} \mathrm{C}$ for plitidepsin analysis; the remaining sample was centrifuged at $2500 \mathrm{~g}$ for $15 \mathrm{~min}$ to obtain the plasma fraction, which was then stored at $-20{ }^{\circ} \mathrm{C}$ for DTIC analysis. Concentrations of plitidepsin and DTIC were determined using a validated high-performance liquid chromatography system coupled with electrospray ionisation tandem mass spectrometry (HPLCMS/MS) (Celli et al, 2004). The lower limits of quantification (LLOQs) were $0.25 \mathrm{ng} \mathrm{ml}^{-1}$ for plitidepsin and $4.98 \mathrm{ngml}$ for DTIC. Complete concentration-time profiles were analysed by standard noncompartmental methods.

\section{RESULTS}

\section{Patient characteristics}

Phase I stage. A total of 28 patients were enrolled (Table 2). Of these, 26 (96\%) had metastatic disease and 16 (59\%) had $\geqslant 3$ sites of disease. At baseline, 27 patients (96\%) had an ECOG PS of $0-1$. The median lactate dehydrogenase $(\mathrm{LDH})$ level was $0.8 \times$ ULN (range, $0.4-3.4 \times \mathrm{ULN}$ ).

Phase II stage

Plitidepsin/DTIC: In all, 38 patients were enrolled, all with metastatic disease (Table 2). Of these, 24 (65\%) had $\geqslant 3$ sites of disease. At baseline, 37 patients (97\%) had an ECOG PS of 0-1. The median LDH level was $0.8 \times \mathrm{ULN}$ (range, $0.4-8.2 \times \mathrm{ULN}$ ).
Single-agent plitidepsin: A total of 20 patients were included (Table 2). All had metastatic disease and $16(80 \%)$ had $\geqslant 3$ sites of disease. Nineteen patients (95\%) had an ECOG PS of $0-1$. The median LDH level was $1.7 \times \mathrm{ULN}$ (range, 0.5-3.9 $\times \mathrm{ULN}$ ).

\section{Treatment exposure}

Phase I stage. Dose ranges during escalation are shown in Table 1. A median of two cycles (range, 1-8 cycles) was administered to each patient. Dose-limiting toxicity (grade 3 ALT increases) occurred in one of five patients treated at dose level 2 (plitidepsin $2.4 \mathrm{mg} \mathrm{m}^{-2}$ and DTIC $800 \mathrm{mg} \mathrm{m}^{-2}$; Table 1). No patients treated at dose level 3 (plitidepsin $3.0 \mathrm{mg} \mathrm{m}^{-2}$ and DTIC $800 \mathrm{mg} \mathrm{m}^{-2}$ ) had DLTs, but dose omissions on day 8 or 15 occurred in $57 \%$ of cycles administered at this dose level, all because of grade $2 / 3$ transaminase increases. At dose level 4 (plitidepsin $2.4 \mathrm{mg} \mathrm{m}^{-2}$ and DTIC $1000 \mathrm{mg} \mathrm{m}^{-2}$ ), DLTs (grade 3 ALT increase, grade 4 pancytopenia and febrile neutropenia) occurred in two of four evaluable patients. Consequently, this dose level was declared the MTD for the plitidepsin/DTIC combination, and dose level 2 (plitidepsin $2.4 \mathrm{mg} \mathrm{m}^{-2}$ and DTIC $800 \mathrm{mg} \mathrm{m}^{-2}$ ) was considered the RD.

At the $\mathrm{RD}$, median plitidepsin dose intensity was $1.2 \mathrm{mg} \mathrm{m}^{-2}$ per week (range, $0.6-2.0 \mathrm{mg} \mathrm{m}^{-2}$ per week) and median relative plitidepsin dose intensity was 67\% (range, 33.1-99.2\%). For DTIC, median dose intensity at the RD was $189.5 \mathrm{mg} \mathrm{m}^{-2}$ per week (range, $151.0-198.9 \mathrm{mg} \mathrm{m}^{-2}$ per week) and median relative dose intensity was $94.8 \%$ (range, 75.5-99.5\%).

\section{Phase II stage}

Plitidepsin/DTIC: A total of 125 cycles were administered, for a median of 2 cycles (range, 1-11 cycles) per patient. Median plitidepsin dose intensity was $1.1 \mathrm{mg} \mathrm{m}^{-2}$ per week (range, $0.6-1.8 \mathrm{mg} \mathrm{m}^{-2}$ per week) and median relative dose intensity was 62\% (range, 33.0-100.0\%). For DTIC, median dose intensity was $199.8 \mathrm{mg} \mathrm{m}^{-2}$ per week (range, $99.7-203.1 \mathrm{mg} \mathrm{m}^{-2}$ per week) and median relative dose intensity was 99.9\% (range, 49.9-101.6\%).

Single-agent plitidepsin: A total of 32 cycles were administered, for a median of 1.5 cycles (range, 1-4 cycles) per patient. Median plitidepsin dose intensity was $1.6 \mathrm{mg} \mathrm{m}^{-2}$ per week (range, $0.8-2.4 \mathrm{mg} \mathrm{m}^{-2}$ per week) and median relative dose intensity was $67 \%$ (range, $31.7-100.9 \%$ ).

\section{Efficacy}

Phase I stage. In all, 19 treated patients were evaluable for efficacy. Antitumour activity in this phase consisted of one confirmed PR, two unconfirmed partial responses $(\mathrm{PRu})$ and four4 disease stabilisations $\geqslant 3$ months.

Phase II stage. Eight patients treated with plitidepsin/DTIC and four treated with single-agent plitidepsin were not evaluable because they either withdrew from the study before receiving the minimum treatment required or did not have disease assessment at least 8 weeks after treatment onset. Reasons for discontinuation comprised toxicity $(n=8)$, AEs unrelated to treatment $(n=2)$ or early disease progression $(n=2)$.

Plitidepsin/DTIC: Of the 28 evaluable patients, 6 showed objective confirmed responses ( $1 \mathrm{CR}$ and 5 PRs; ORR $=21.4 \%$, $95 \%$ CI, $8.3-41.0 \%$; Table 3 ). The CR occurred in a 21 -year-old female with multiple metastatic lesions (3 in the lungs) who received a total of 9 cycles. Tumour lesions decreased in size after cycle 2 and were undetectable after cycle 9, with no subsequent disease progression at last follow-up (18.7 months after treatment onset). All patients responding to plitidepsin/DTIC had LDH $\leqslant 1.1 \times$ ULN and an ECOG PS $\leqslant 1$ at baseline. Median duration of response was 4.5 months (range, 1.4-16.5 + months). In addition, 


\begin{tabular}{|c|c|c|c|}
\hline & \multicolumn{3}{|c|}{ Phase II stage } \\
\hline & Phase I stage $(n=28)$ & Plitidepsin $(n=20)$ & Plitidepsin/DTIC $(n=38)$ \\
\hline \multicolumn{4}{|l|}{ Gender } \\
\hline Male & $16(57 \%)$ & $10(50 \%)$ & $21(55 \%)$ \\
\hline Female & $12(43 \%)$ & $10(50 \%)$ & $17(45 \%)$ \\
\hline Median age (years) (range) & $48.0(20-77)$ & $51.5(36-78)$ & $55.5(21-76)$ \\
\hline \multicolumn{4}{|l|}{ ECOG performance status } \\
\hline 0 & $16(57 \%)$ & $4(20 \%)$ & $21(55 \%)$ \\
\hline 1 & $11(39 \%)$ & $15(75 \%)$ & $16(42 \%)$ \\
\hline 2 & $1(4 \%)$ & $1(5 \%)$ & $1(3 \%)$ \\
\hline Median plasma LDH ( $\times$ ULN) (range) & $0.8(0.4-3.4)$ & $1.7(0.5-3.9)$ & $0.8(0.4-8.2)$ \\
\hline$\leqslant 1.1 \times$ ULN & 20 (71\%) & $4(20 \%)$ & $23(61 \%)$ \\
\hline$>1.1 \times$ ULN & $8(29 \%)$ & $16(80 \%)$ & 15 (39\%) \\
\hline \multicolumn{4}{|l|}{ Disease $^{a}$} \\
\hline Metastatic & $26(96 \%)$ & $20(100 \%)$ & $38(100 \%)$ \\
\hline Locally advanced & $1(4 \%)$ & & \\
\hline \multicolumn{4}{|l|}{ Sites of disease ${ }^{a}$} \\
\hline Lung & 19 (70\%) & $11(55 \%)$ & $25(68 \%)$ \\
\hline Lymph node & $18(67 \%)$ & 17 (85\%) & $27(73 \%)$ \\
\hline Soft tissue & 9 (33\%) & 5 (25\%) & $11(30 \%)$ \\
\hline Liver & 8 (30\%) & $11(55 \%)$ & 17 (46\%) \\
\hline Bone & 7 (26\%) & 7 (35\%) & $6(16 \%)$ \\
\hline Peritoneum & $4(15 \%)$ & $4(20 \%)$ & $6(16 \%)$ \\
\hline Pelvis & $3(11 \%)$ & $1(5 \%)$ & $5(14 \%)$ \\
\hline Skin & $2(7 \%)$ & $3(15 \%)$ & $1(3 \%)$ \\
\hline Spleen & $2(7 \%)$ & $4(20 \%)$ & $3(8 \%)$ \\
\hline Kidney & $1(4 \%)$ & $1(5 \%)$ & 5 (14\%) \\
\hline Other ${ }^{b}$ & $5(19 \%)$ & $5(25 \%)$ & $12(32 \%)$ \\
\hline \multicolumn{4}{|l|}{ Number of sites of disease $e^{a, c}$} \\
\hline 1-2 Sites & $11(41 \%)$ & $4(20 \%)$ & $13(35 \%)$ \\
\hline$\geqslant 3$ Sites & $16(59 \%)$ & $16(80 \%)$ & $24(65 \%)$ \\
\hline \multicolumn{4}{|l|}{ Previous anticancer therapy } \\
\hline Surgery & $28(100 \%)$ & $20(100 \%)$ & $36(95 \%)$ \\
\hline Radiotherapy & $10(36 \%)$ & $10(50 \%)$ & 7 (18\%) \\
\hline Biological therapy & $2(7 \%)$ & 1 (5\%) & $2(5 \%)$ \\
\hline Chemotherapy ${ }^{d}$ & & & $1(3 \%)$ \\
\hline \multicolumn{4}{|c|}{ 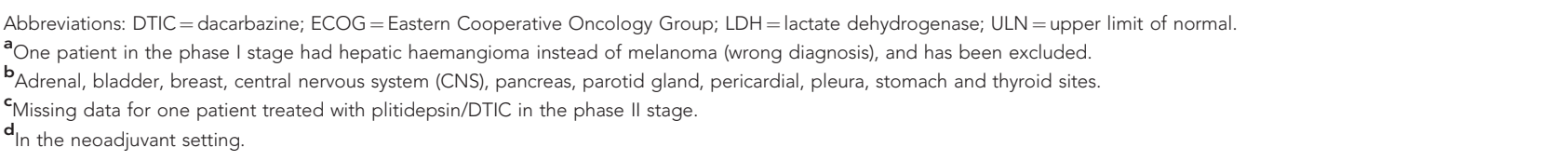 } \\
\hline
\end{tabular}

9 patients (32.1\%) had disease stabilisation (including $1 \mathrm{PRu}$ ) for a median of 3.9 months (range, 3.1-13.2 months). In the whole cohort of 28 evaluable patients, median progression-free survival (PFS) was 3.3 months (95\% CI, 1.6-4.6 months) and median OS was not reached before the database lock (Figure 1). Median PFS was 4.3 months (95\% CI, 2.0-7.9 months) in 20 patients with baseline $\mathrm{LDH} \leqslant 1.1 \times \mathrm{ULN}$ (Table 3 ).

Single-agent plitidepsin: None of the 16 evaluable patients achieved objective response. Two (12.5\%) had disease stabilisation (median duration of 2.9 months; range, 2.8-3.0 months; Table 3). Median PFS for all 16 patients was 1.5 months (95\% CI, 0.9-1.9 months; Figure 1) and median OS was 4.1 months (95\% CI, 1.5-7.7 months). Median PFS was 1.6 months (95\% CI, 1.6-2.8 months) in 3 patients with $\mathrm{LDH} \leqslant 1.1 \times \mathrm{ULN}$ (Table 3 ).

\section{Toxicity profile}

Phase I stage (at the $R D$ ). All five patients treated at the $\mathrm{RD}$ were evaluable for safety. Most toxicities were grade 1/2. Clinically relevant toxicities comprised grade 3 fatigue $(n=2$, concomitant with grade 4 neutropenic sepsis in one case), grade 3 vomiting, grade 3 diarrhoea, grade 3 hypersensitivity, grade 3 respiratory tract infection, grade 3 weakness and grade 4 pancytopenia $(n=1)$. Transient grade 3 ALT increase occurred in 2 patients. 


\begin{tabular}{|c|c|c|c|c|}
\hline & \multicolumn{2}{|c|}{ Plitidepsin $(n=16)$} & \multicolumn{2}{|c|}{ Plitidepsin/DTIC $(\boldsymbol{n}=\mathbf{2 8})$} \\
\hline & $n$ & $\%$ & $n$ & $\%$ \\
\hline Complete response & & & 1 & 3.6 \\
\hline Partial response & & & $5^{a}$ & 17.9 \\
\hline Stable disease & 2 & 12.5 & $9^{b}$ & 32.1 \\
\hline \multirow[t]{2}{*}{ Progressive disease } & 14 & 87.5 & 13 & 46.4 \\
\hline & Median (months) & Range & Median (months) & Range \\
\hline Duration of response & & & 4.5 & $1.4-16.5$ \\
\hline \multirow[t]{2}{*}{ Duration of stable disease } & 2.9 & $2.8-3.0$ & 3.9 & $3.1-13.2$ \\
\hline & Median (months) & $95 \% \mathrm{Cl}$ & Median (months) & $95 \% \mathrm{Cl}$ \\
\hline \multicolumn{5}{|l|}{ All evaluable patients } \\
\hline $\begin{array}{l}n \\
\text { PFS }\end{array}$ & $\begin{array}{l}16 \\
1.5\end{array}$ & $0.9-1.9$ & $\begin{array}{l}28 \\
3.3\end{array}$ & $1.6-4.6$ \\
\hline \multicolumn{5}{|c|}{ Patients with baseline LDH $\leqslant 1.1 \times$ ULN } \\
\hline $\begin{array}{l}n \\
\text { PFS }\end{array}$ & $\begin{array}{c}3 \\
1.6\end{array}$ & $1.6-2.8$ & $\begin{array}{l}20 \\
4.3\end{array}$ & $2.0-7.9$ \\
\hline \multicolumn{5}{|c|}{ Patients with baseline LDH $>1.1 \times$ ULN } \\
\hline $\begin{array}{l}n \\
\text { PFS }\end{array}$ & $\begin{array}{l}13 \\
1.1\end{array}$ & $0.9-1.9$ & $\begin{array}{c}8 \\
1.4\end{array}$ & $1.1-1.6$ \\
\hline
\end{tabular}

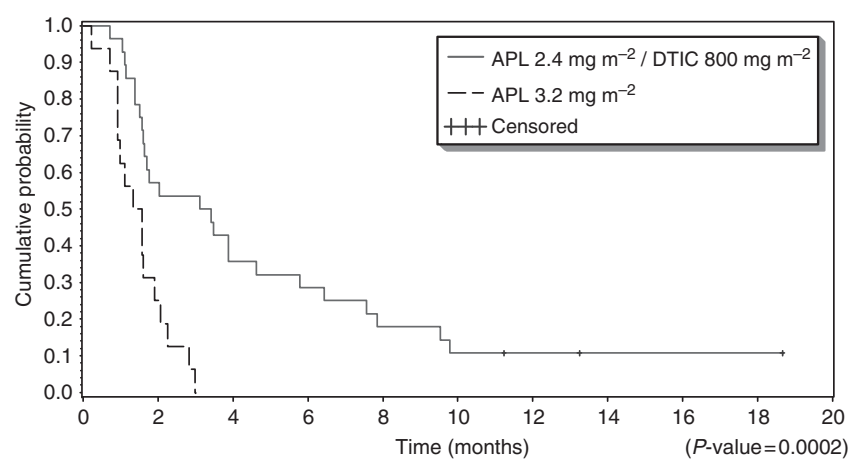

Figure 1. Progression-free survival of patients treated with plitidepsin alone or with plitidepsin/DTIC during the phase II stage.

Phase II stage. Of the 58 enrolled patients, 56 were treated and were evaluable for safety. The most common nonhaematological toxicities were ALT/AST increases, AP increases, fatigue, nausea and vomiting (in both arms), plus CPK increase with single-agent plitidepsin, and total bilirubin increase with plitidepsin/DTIC (Table 4). Severe AEs occurred rarely, mostly reaching grade 3 at worst, and were properly managed with dose adjustments.

All transaminase increases in both arms were transient. Grade 3 ALT increases were more frequent with plitidepsin/DTIC (28\% vs $10 \%$ of patients); grade 3 AST increases were rarer and only occurred with plitidepsin/DTIC (6\% of patients). It is noteworthy that more patients treated with the combination skipped at least one plitidepsin infusion (77\% vs 47\%) and more omissions were because of treatment-related transaminase increases (65\% vs 25\%) as compared with plitidepsin alone. Most omissions involved the plitidepsin infusion on day 8 . In contrast, grade $3 / 4$ CPK increase occurred more frequently with single-agent plitidepsin (15\% vs 3\% of patients).

The most common haematological abnormalities were anaemia and lymphopenia (Table 4). Most were mild or moderate. Severe abnormalities occurred in 2 patients (10\%) treated with singleagent plitidepsin and $4(11 \%)$ treated with plitidepsin/DTIC. All other haematological abnormalities were mild and had no effects on treatment compliance. Notably, no cases of febrile neutropenia were observed.

Hypersensitivity reactions $(n=14)$ were more frequent with plitidepsin/DTIC ( $n=9$ patients, $25 \%$ vs $n=3$ patients with singleagent plitidepsin, $15 \%$ ) and resulted in the treatment discontinuation of 7 patients ( $5 v s 2$, respectively). Nevertheless, one patient in each arm had grade $2 / 3$ hypersensitivity reactions but continued treatment safely without reoccurrence of the events.

Pharmacokinetics. Complete PK data were available from 67 patients (21 during the phase I stage and 46 during the phase II stage) for plitidepsin, and from 49 patients (17 and 32, respectively) for DTIC (Table 5). The mean maximum plasma concentrations $\left(\mathrm{C}_{\max }\right)$, area under the curve (AUC) and terminal half-life $\left(t_{1 / 2}\right)$ of plitidepsin were similar when the drug was administered at $3.2 \mathrm{mg} \mathrm{m}^{-2}$ as single agent or at $2.4 \mathrm{mg} \mathrm{m}^{-2}$ combined with DTIC $800 \mathrm{mg} \mathrm{m}^{-2}$. Maximum plitidepsin concentrations were typically observed during or immediately before the end of infusion and then decreased in a multiexponential manner, with an initial rapid decline followed by a more prolonged 


\begin{tabular}{|c|c|c|c|c|c|c|}
\hline & \multicolumn{3}{|c|}{ Plitidepsin $(n=20)$} & \multicolumn{3}{|c|}{ Plitidepsin/DTIC $(n=36)^{a}$} \\
\hline & Grade $1 / 4$ & Grade 3 & Grade 4 & Grade $1 / 4$ & Grade 3 & Grade 4 \\
\hline \multicolumn{7}{|l|}{ Nonhaematological } \\
\hline $\begin{array}{l}\text { ALT increase } \\
\text { Anorexia } \\
\text { AP increase } \\
\text { AST increase } \\
\text { Constipation } \\
\text { CPK increase } \\
\text { Creatinine increase } \\
\text { Diarrhoea } \\
\text { Electrocardiogram T wave abnormal } \\
\text { Fatigue } \\
\text { Hypersensitivity } \\
\text { Muscle cramps } \\
\text { Muscle weakness } \\
\text { Myalgia } \\
\text { Nausea } \\
\text { Total bilirubin increased } \\
\text { Vomiting } \\
\text { Weight decrease }\end{array}$ & $\begin{array}{r}18(90 \%) \\
2(10 \%) \\
11(55 \%) \\
15(75 \%) \\
3(15 \%) \\
7(35 \%) \\
4(20 \%) \\
3(15 \%) \\
8(40 \%) \\
3(15 \%) \\
2(10 \%) \\
1(5 \%) \\
4(20 \%) \\
9(45 \%) \\
5(25 \%) \\
6(30 \%)\end{array}$ & $\begin{array}{l}2(10 \%) \\
2(10 \%) \\
1(5 \%) \\
1(5 \%) \\
1(5 \%) \\
2(10 \%) \\
1(5 \%)\end{array}$ & $1(5 \%)$ & $\begin{array}{r}33(92 \%) \\
6(17 \%) \\
14(39 \%) \\
25(69 \%) \\
4(11 \%) \\
7(19 \%) \\
5(14 \%) \\
7(19 \%) \\
4(11 \%) \\
15(42 \%) \\
9(25 \%) \\
3(8 \%) \\
5(14 \%) \\
4(11 \%) \\
25(69 \%) \\
19(53 \%) \\
13(36 \%) \\
4(11 \%)\end{array}$ & $\begin{array}{l}9(25 \%) \\
2(6 \%) \\
1(3 \%) \\
4(11 \%) \\
3(8 \%) \\
1(3 \%) \\
2(6 \%) \\
1(3 \%) \\
2(6 \%)\end{array}$ & $\begin{array}{l}1(3 \%) \\
1(3 \%)\end{array}$ \\
\hline \multicolumn{7}{|l|}{ Haematological } \\
\hline $\begin{array}{l}\text { Anaemia } \\
\text { Leukopenia } \\
\text { Lymphopenia } \\
\text { Neutropenia } \\
\text { Thrombocytopenia }\end{array}$ & $\begin{array}{l}11(55 \%) \\
11(55 \%) \\
5(25 \%)\end{array}$ & $1(5 \%)$ & $1(5 \%)$ & $\begin{array}{r}23(64 \%) \\
9(25 \%) \\
19(53 \%) \\
10(28 \%) \\
5(14 \%)\end{array}$ & $1(3 \%)$ & $\begin{array}{l}1(3 \%) \\
1(3 \%) \\
2(6 \%) \\
2(6 \%)\end{array}$ \\
\hline $\begin{array}{l}\text { Abbreviations: } A L T=\text { alanine aminotransfera } \\
\text { evaluable for safety. Data shown are numbe } \\
\text { shown regardless of their relationship to tre } \\
a_{\text {Two patients enrolled into this cohort were }} \\
\mathrm{b}_{\text {These comprised grade } 2 \text { electrocardiograr }}\end{array}$ & $\begin{array}{l}=\text { alkaline phosp } \\
\text { oatients. Only t } \\
\text { wn before rece } \\
\text { inversion }(n=\end{array}$ & $\begin{array}{l}\text { AST }=\text { aspart } \\
\text { found in } \geqslant 1 \\
\text { first infusion } \\
2 \text { electrocar }\end{array}$ & $\begin{array}{l}\text { transferase; } \\
\text { ents with eitl } \\
\text { were not ev } \\
\text { wave abnorr }\end{array}$ & $\begin{array}{l}\text { eatine phospho } \\
\text { nent are includ } \\
\text { or safety. } \\
\text { grade } 1 \text { electroc }\end{array}$ & $\begin{array}{l}\text { TIC }=\text { dacarbc } \\
\text { atological anc } \\
\text { T wave amp }\end{array}$ & $\begin{array}{l}\text { umber of pat } \\
\text { abnormalitie } \\
\text { eased }(n=1 \mathrm{e}\end{array}$ \\
\hline
\end{tabular}

distribution. Both whole blood clearance (CL) and volume of distribution at steady state $\left(V_{\mathrm{ss}}\right)$ of plitidepsin were higher when administered alone. The mean PK parameters observed for DTIC in this study do not show significant changes between different plitidepsin dose levels. No interaction between plitidepsin and DTIC was found.

\section{DISCUSSION}

Plitidepsin is a compound with high pleiotropicity, affecting multiple cell signalling pathways and targets (Munoz-Alonso et al, 2009). Plitidepsin inhibits cell cycle progression, induces apoptosis and shows antiangiogenic activity. These effects are related to the induction of early oxidative stress, the activation of Rac1 GTPase and the inhibition of protein phosphatases, which together cause sustained activation of two members of the MAPK family: the serine/threonine kinases JNK and p38 MAPK (Cuadrado et al, 2003). Sensitivity to plitidepsin is inversely correlated with the level of expression of the Cdk inhibitor p27kip1 in a panel of lowpassage human sarcoma cell lines. Furthermore, the elimination of p27kip1 in these cells (by siRNA) or in mouse embryo fibroblasts (MEFs; p27 kip1 knockout) increases their sensitivity to plitidepsin (Moneo et al, 2007). Phosphorylated JNK has recently been described as a pharmacodynamic biomarker of plitidepsin in xenografted tumours as well as in normal surrogate tissues (Munoz-Alonso et al, 2013).
The first stage of this phase I-II clinical trial found plitidepsin $2.4 \mathrm{mg} \mathrm{m}^{-2}$ plus DTIC $800 \mathrm{mg} \mathrm{m}^{-2}$ as the RD for plitidepsin 1-h infusion (days 1, 8 and 15) plus DTIC 1-h infusion (day 1) q4wk regimen in chemonaive adult patients with advanced malignant melanoma. Unsurprisingly, transient grade 3 ALT increase was the most common DLT during dose escalation, which was similar to the findings of prior plitidepsin studies (Anthoney et al, 2000; Ciruelos et al, 2002; Faivre et al, 2005; Izquierdo et al, 2008; Gomez-Roca et al, 2010; Stein et al, 2012). Dose-limiting grade 4 febrile neutropenia and grade 4 pancytopenia occurred in one patient at the MTD, which was the only level in which DTIC was administered at $1000 \mathrm{mg} \mathrm{m}^{-2}$. Haematological toxicity is more likely to be linked to DTIC (Chapman et al, 1999) rather than to plitidepsin, as it is seldom reported in single-agent studies in patients with nonhaematological tumours (Faivre et al, 2005; Maroun et al, 2006; Izquierdo et al, 2008).

The second stage of this study explored the efficacy of plitidepsin alone or in combination with DTIC. The ORR of $21.4 \%$ found for patients treated with the combination is within the ranges (11-31\%) reported for DTIC combined with other active agents in metastatic melanoma, including ipilimumab, for which an ORR of $15.2 \%$ was reported in a recent phase III trial (Robert et al, 2011). Vemurafenib has resulted in a higher response rate $(55 \%)$ in advanced melanoma patients with a BRAF V600E mutation (Chapman et al, 2012); however, this mutation is only present in $\sim 50 \%$ of all melanoma patients. Much lower response rates have been reported for single-agent DTIC (range, 5-15\%), thus suggesting that the combination of plitidepsin plus DTIC may 
Table 5. Pharmacokinetic parameters of plitidepsin and DTIC in cycle 1

\begin{tabular}{|c|c|c|c|c|c|c|}
\hline Plitidepsin/DTIC dose level $\left(\mathrm{mg} \mathrm{m}^{-2}\right.$ ) & $n$ & $\mathrm{C}_{\max }\left(\mathrm{ng} \mathrm{ml^{-1 }}\right)$ & AUC $\left(\mathrm{h} \times \mathrm{ng} \mathrm{ml}^{-1}\right)$ & $t_{1 / 2}(h)$ & $\mathrm{CL}\left(\mathrm{Ih}^{-1}\right)$ & $V_{\mathrm{ss}}(\mathrm{l})$ \\
\hline \multicolumn{7}{|l|}{ Plitidepsin } \\
\hline \multicolumn{7}{|l|}{ Phase I stage } \\
\hline $\begin{array}{l}1.8 / 800 \\
2.4 / 800 \text { (RD) } \\
3.0 / 800 \\
2.4 / 1000 \text { (MTD) }\end{array}$ & $\begin{array}{l}6 \\
6 \\
7 \\
2\end{array}$ & $\begin{array}{l}41.7(25.6-50.4) \\
42.4(30.0-49.8) \\
38.1(24.6-49.0) \\
36.0(35.5-36.4)\end{array}$ & $\begin{array}{l}540(240-824) \\
508(262-727) \\
323(212-523) \\
277(184-369)\end{array}$ & $\begin{array}{l}42.7(32.2-56.5) \\
39.5(16.3-53.6) \\
38.8(15.4-69.1) \\
16.1(15.1-17.0)\end{array}$ & $\begin{array}{c}7.1(3.8-12.1) \\
10.4(7.6-17.0) \\
19.0(11.9-28.3) \\
16.7(11.1-22.2)\end{array}$ & $\begin{array}{l}261(175-401) \\
408(163-590) \\
750(316-1920) \\
299(245-353)\end{array}$ \\
\hline \multicolumn{7}{|l|}{ Phase II stage } \\
\hline $\begin{array}{l}3.2 \\
2.4 / 800\end{array}$ & $\begin{array}{l}17 \\
29\end{array}$ & $\begin{array}{l}38.3(16.1-48.4) \\
40.3(26.2-50.2)\end{array}$ & $\begin{array}{l}444(205-848) \\
425(215-1130)\end{array}$ & $\begin{array}{l}45.1(14.2-131) \\
43.0(13.7-85.5)\end{array}$ & $\begin{array}{l}15.4(7.5-24.5) \\
12.0(4.0-24.9)\end{array}$ & $\begin{array}{l}652(198-1380) \\
456(158-826)\end{array}$ \\
\hline \multicolumn{7}{|l|}{ DTIC } \\
\hline \multicolumn{7}{|l|}{ Phase I stage } \\
\hline $\begin{array}{l}1.8 / 800 \\
2.4 / 800 \text { (RD) } \\
3.0 / 800 \\
2.4 / 1000 \text { (MTD) }\end{array}$ & $\begin{array}{l}5 \\
7 \\
4 \\
1\end{array}$ & $\begin{array}{c}19.9(15.1-23.9) \\
18.2(5.0-24.4) \\
16.1(4.2-22.9) \\
4.6(-)\end{array}$ & $\begin{array}{l}46.0(30.3-69.8) \\
42.3(24.5-66.8) \\
48.2(14.8-84.9) \\
15.7(-)\end{array}$ & $\begin{array}{l}1.3(0.7-2.4) \\
1.4(0.5-1.9) \\
2.5(2.2-2.9) \\
3.5(-)\end{array}$ & $\begin{array}{l}35.2(22.4-47.8) \\
41.8(22.3-68.6) \\
41.3(18.9-86.6) \\
114(-)\end{array}$ & $\begin{array}{l}50.6(37.1-66.1) \\
76.7(28.4-185) \\
94.8(63.7-156) \\
385(-)\end{array}$ \\
\hline \multicolumn{7}{|l|}{ Phase II stage } \\
\hline $2.4 / 800$ & 32 & $15.4(4.3-22.6)$ & $38.3(13.6-60.8)$ & $2.6(1.2-6.7)$ & $42.8(22-124)$ & $96.2(45.8-249)$ \\
\hline
\end{tabular}

indeed have had a synergistic antitumour effect. Moreover, as the DTIC dose given $\left(800 \mathrm{mg} \mathrm{m}^{-2} \mathrm{q} 4 \mathrm{wk}\right)$ is lower than the one usually administered to patients with metastatic melanoma (Mouawad et al, 2010), this might have also resulted in a much lower haematological toxicity compared with full-dose DTIC. The finding that all six responders to plitidepsin/DTIC in the second study stage had serum LDH levels $\leqslant 1.1 \times$ ULN and an ECOG PS $\leqslant 1$ at baseline is intriguing, but may reflect an imbalance for known prognostic factors in both arms, and that these patients were in better condition or had better prognosis.

No responses occurred with single-agent plitidepsin. This lack of response may be partly related to the patients' poor prognosis at baseline because of lack of stratification. Known prognostic factors, such as high serum LDH (an independent and highly significant predictor of survival in advanced melanoma) (Balch et al, 2003; Bedikian et al, 2008; Neuman et al, 2008), ECOG PS or the presence of visceral metastases, were not taken into account owing to the small number of patients planned to be included in this small phase I-II study. During the second stage, more patients in the combination arm had baseline LDH $\leqslant 1.1 \times$ ULN $(61 \% v s$ $20 \%)$ and ECOG PS $=0$ (55\% vs 20\%), and fewer had $\geqslant 3$ sites of disease at baseline (65\% vs $80 \%)$. These differences suggest, in a post hoc analysis, that a better prognosis at baseline favoured patients included in the combination arm, and might have contributed towards the different response to treatment achieved in each arm.

Small differences were found between the safety profiles of single-agent plitidepsin and plitidepsin/DTIC. Nevertheless, both regimens were generally well tolerated and showed manageable toxicity. The overall toxicity profile of single-agent plitidepsin agrees with that previously reported for this same schedule (Ferme et al, 2008; Izquierdo et al, 2008). The addition of DTIC might have contributed towards the slightly greater incidence of nausea, fatigue, vomiting and transaminase increases found with the combination, although these toxicities are also frequently reported with DTIC monotherapy (Patel et al, 2011). The hypersensitivity reactions related to plitidepsin/DTIC were more common and more severe than expected, based on the toxicity profiles reported for either drug alone (Chapman et al, 1999; Ferme et al, 2008; Izquierdo et al, 2008; Patel et al, 2011); the reasons underlying this finding remain to be elucidated.

Biochemical abnormalities occurred at similar frequencies in both regimens, although transaminase increases were slightly more frequent with the combination. Most patients (77\%) treated with the combination skipped at least one plitidepsin infusion, generally because of treatment-related ALT or AST increases and involving the Day 8 infusion. Skipping the Day 8 infusion generally resulted in resolution and did not compromise further dosing. Thus, a fortnightly schedule might be more convenient for plitidepsin when combined with DTIC in the treatment of metastatic melanoma.

As expected, haematological abnormalities were more frequent with plitidepsin/DTIC than with plitidepsin alone. Neutropenia only occurred with the combination. However, only $11 \%$ of patients treated with the combination had severe haematological abnormalities resulting in treatment delay or dose reduction. Severe bone marrow depletion has been reported as a frequent reason for discontinuation in DTIC-based chemotherapies (Jungnelius et al, 1998; Agarwala et al, 1999; Chapman et al, 1999; Chiarion Sileni et al, 2001; Jelic et al, 2002). Overall, these results suggest that addition of plitidepsin may improve the antitumour efficacy of DTIC in metastatic melanoma while not increasing its known haematological toxicity.

The overall whole blood PK parameters obtained for plitidepsin alone or combined with DTIC were similar to those found in a previous phase I study (Izquierdo et al, 2008). The profile was characterised by a long half-life, low clearance and a high volume of distribution. Drug levels peaked during or immediately before the end of infusion, and then decreased in a multiexponential manner. The mean plasma PK parameters found for DTIC were also similar to those reported in previous studies (Buesa and Urrechaga, 1991). Therefore, no drug-drug PK interactions were apparent. 
This study was initiated before the availability of BRAF inhibitors and targeted immune therapies. It is unclear now how to assess a precise role for the plitidepsin/DTIC combination in the rapidly changing treatment options for advanced melanoma. Patient selection by BRAF status has led to high response rates but not durable responses in BRAF V600E-mutated melanoma and overall survival is improved with treatment with ipilimumab. Despite these improvements, most patients with advanced melanoma will ultimately progress and die of their disease; thus, new treatment options are still needed. The results of this study are promising, taking into account the novel mechanism of action of plitidepsin, which allows the drug to act synergistically with DTIC without adding harmful toxicity.

In conclusion, this phase I-II study shows plitidepsin $2.4 \mathrm{mg} \mathrm{m}^{-2} 1$-h infusion (days 1,8 and 15) plus DTIC $800 \mathrm{mg} \mathrm{m}^{-2} 1$-h infusion (day 1) $\mathrm{q} 4 \mathrm{wk}$ as an active, well-tolerated, first-line chemotherapy against metastatic melanoma. Further evaluation of plitidepsin/DTIC as a fortnightly schedule might be warranted in non-BRAF-mutated advanced melanoma patients.

\section{REFERENCES}

Agarwala SS (2009) Current systemic therapy for metastatic melanoma. Expert Rev Anticancer Ther 9: 587-595.

Agarwala SS, Ferri W, Gooding W, Kirkwood JM (1999) A phase III randomized trial of dacarbazine and carboplatin with and without tamoxifen in the treatment of patients with metastatic melanoma. Cancer 85: 1979-1984.

Anthoney A, Paz-Ares L, Twelves C, Cortes-Funes H, Kaye S, Pronk L, Celli N, Lopez-Lazaro L, Guzman C, Jimeno J (2000) Phase I and pharmacokinetic (PK) study of Aplidin (APL) using a 24-hour, weekly schedule. Proc Am Soc Clin Oncol 19: Abstract 734.

Avril MF, Aamdal S, Grob JJ, Hauschild A, Mohr P, Bonerandi JJ, Weichenthal M, Neuber K, Bieber T, Gilde K, Guillem Porta V, Fra J, Bonneterre J, Saiag P, Kamanabrou D, Pehamberger H, Sufliarsky J, Gonzalez Larriba JL, Scherrer A, Menu Y (2004) Fotemustine compared with dacarbazine in patients with disseminated malignant melanoma: a phase III study. J Clin Oncol 22: 1118-1125.

Balch CM, Buzaid AC, Soong SJ, Atkins MB, Cascinelli N, Coit DG, Fleming ID, Gershenwald JE, Houghton Jr A, Kirkwood JM, McMasters KM, Mihm MF, Morton DL, Reintgen DS, Ross MI, Sober A, Thompson JA, Thompson JF (2003) New TNM melanoma staging system: linking biology and natural history to clinical outcomes. Semin Surg Oncol 21: 43-52.

Bedikian AY, Johnson MM, Warneke CL, Papadopoulos NE, Kim K, Hwu WJ, McIntyre S, Hwu P (2008) Prognostic factors that determine the long-term survival of patients with unresectable metastatic melanoma. Cancer Invest 26: 624-633.

Bedikian AY, Millward M, Pehamberger H, Conry R, Gore M, Trefzer U, Pavlick AC, DeConti R, Hersh EM, Hersey P, Kirkwood JM, Haluska FG (2006) Bcl-2 antisense (oblimersen sodium) plus dacarbazine in patients with advanced melanoma: the Oblimersen Melanoma Study Group. J Clin Oncol 24: 4738-4745.

Buesa JM, Urrechaga E (1991) Clinical pharmacokinetics of high-dose DTIC. Cancer Chemother Pharmacol 28: 475-479.

Celli N, Mariani B, Di Carlo F, Zucchetti M, Lopez-Lazaro L, D’Incalci M, Rotilio D (2004) Determination of aplidin (dehydrodidemnin B) in human plasma, whole blood and urine by liquid chromatography with electrospray ionisation tandem mass spectrometry detection. J Pharm Biomed Anal 34: 619-630.

Chapman PB, Einhorn LH, Meyers ML, Saxman S, Destro AN, Panageas KS, Begg CB, Agarwala SS, Schuchter LM, Ernstoff MS, Houghton AN, Kirkwood JM (1999) Phase III multicenter randomized trial of the Dartmouth regimen versus dacarbazine in patients with metastatic melanoma. J Clin Oncol 17: 2745-2751.

Chapman PB, Hauschild A, Robert C, Larkin JMG, JBAG Haanen, Ribas A, Hogg D, Hamid O, Ascierto PA, Testori A, Lorigan P, Dummer R, Sosman JA, Garbe C, Maio M, Nolop KB, Nelson BJ, Joe AK, Flaherty KT, McArthur GA (2012) Updated overall survival (OS) results for BRIM-3, a phase III randomized, open-label, multicenter trial comparing BRAF inhibitor vemurafenib (vem) with dacarbazine (DTIC) in previously untreated patients with BRAFV600E-mutated melanoma. J Clin Oncol 30: Abstract 8502

Chiarion Sileni V, Nortilli R, Aversa SM, Paccagnella A, Medici M, Corti L, Favaretto AG, Cetto GL, Monfardini S (2001) Phase II randomized study of dacarbazine, carmustine, cisplatin and tamoxifen versus dacarbazine alone in advanced melanoma patients. Melanoma Res 11: 189-196.

Ciruelos EM, Twelves C, Dominguez MJ, Mckay H, Anthony A, Castellanos D, Bezares S, Ruiz A, Lopez-Lazaro L, Jimeno J, Celli C, Cortes-Funes H, Paz-Ares L (2002) Phase I clinical and pharmacokinetic study of the marine compound Aplidin (APL) administered as a 3 hour infusion every 2 weeks. Proc Am Soc Clin Oncol 21: Abstract 422.

Cuadrado A, Garcia-Fernandez LF, Gonzalez L, Suarez Y, Losada A, Alcaide V, Martinez T, Fernandez-Sousa JM, Sanchez-Puelles JM, Munoz A (2003) Aplidin induces apoptosis in human cancer cells via glutathione depletion and sustained activation of the epidermal growth factor receptor, Src, JNK, and p38 MAPK. J Biol Chem 278: 241-250.

Eggermont AM, Kirkwood JM (2004) Re-evaluating the role of dacarbazine in metastatic melanoma: what have we learned in 30 years? Eur J Cancer 40: 1825-1836.

Eisen T, Thomas J, Miller Jr. WH, Gore M, Wolter P, Kavan P, Martin JA, Lardelli P (2009) Phase II study of biweekly plitidepsin as second-line therapy in patients with advanced malignant melanoma. Melanoma Res 19: $185-192$.

Faivre S, Chieze S, Delbaldo C, Ady-Vago N, Guzman C, Lopez-Lazaro L, Lozahic S, Jimeno J, Pico F, Armand JP, Martin JA, Raymond E (2005) Phase I and pharmacokinetic study of aplidine, a new marine cyclodepsipeptide in patients with advanced malignancies. J Clin Oncol 23: 7780-7782.

Falkson CI, Ibrahim J, Kirkwood JM, Coates AS, Atkins MB, Blum RH (1998) Phase III trial of dacarbazine versus dacarbazine with interferon alpha-2b versus dacarbazine with tamoxifen versus dacarbazine with interferon alpha- $2 \mathrm{~b}$ and tamoxifen in patients with metastatic malignant melanoma: an Eastern Cooperative Oncology Group study. J Clin Oncol 16: 1743-1751.

Ferme C, Mateos MV, Szyldergemajn S, Zucca E, Espinoza J, Briones J, Morschhauser F, Gisselbrecht C, Ribrag V (2008) Plitidepsin is active in peripheral T-cell lymphoma (PTCL): a subset analysis from an ongoing multicenter phase II trial. Blood 112: Abstract 1566.

Gomez-Roca C, Besse-Hammer T, Szyldergemajn S, Bahleda R, Diaz M, Vandermeeren A, Extremera S, Kahatt C, Soria JC, Awada A (2010) Phase IB study of plitidepsin (APL) with bevacizumab (BEV) in refractory solid tumor patients (pts). Eur J Cancer 8: Abstract 432.

Izquierdo MA, Bowman A, Garcia M, Jodrell D, Martinez M, Pardo B, Gomez J, Lopez-Martin JA, Jimeno J, Germa JR, Smyth JF (2008) Phase I clinical and pharmacokinetic study of plitidepsin as a 1-hour weekly intravenous infusion in patients with advanced solid tumors. Clin Cancer Res 14: 3105-3112.

Jelic S, Babovic N, Kovcin V, Milicevic N, Milanovic N, Popov I, Radosavljevic D (2002) Comparison of the efficacy of two different dosage dacarbazinebased regimens and two regimens without dacarbazine in metastatic melanoma: a single-centre randomized four-arm study. Melanoma Res 12: $91-98$.

Jungnelius U, Ringborg U, Aamdal S, Mattsson J, Stierner U, Ingvar C, Malmstrom P, Andersson R, Karlsson M, Willman K, Wist E, Bjelkengren G, Westberg R (1998) Dacarbazine-vindesine versus dacarbazine-vindesine-cisplatin in disseminated malignant melanoma. A randomised phase III trial. Eur J Cancer 34: 1368-1374.

Lev DC, Onn A, Melinkova VO, Miller C, Stone V, Ruiz M, McGary EC, Ananthaswamy HN, Price JE, Bar-Eli M (2004) Exposure of melanoma cells to dacarbazine results in enhanced tumor growth and metastasis in vivo. J Clin Oncol 22: 2092-2100.

Lev DC, Ruiz M, Mills L, McGary EC, Price JE, Bar-Eli M (2003) Dacarbazine causes transcriptional up-regulation of interleukin 8 and vascular endothelial growth factor in melanoma cells: a possible escape mechanism from chemotherapy. Mol Cancer Ther 2: 753-763.

Maroun JA, Belanger K, Seymour L, Matthews S, Roach J, Dionne J, Soulieres D, Stewart D, Goel R, Charpentier D, Goss G, Tomiak E, Yau J, Jimeno J, Chiritescu G (2006) Phase I study of Aplidine in a dailyx5 one-hour infusion every 3 weeks in patients with solid tumors refractory to standard therapy. A National Cancer Institute of Canada Clinical Trials Group study: NCIC CTG IND 115. Ann Oncol 17: 1371-1378. 
Moneo MV, Serelde BG, Leal JFM, Blanco-Aparicio C, Diaz-Uriarte R, Aracil M, Tercero JC, Jimeno J, Carnero A (2007) Levels of p27kip1 determine Aplidin $\AA$ sensitivity. Mol Cancer Therapeut 6: 1310-1316.

Mouawad R, Sebert M, Michels J, Bloch J, Spano JP, Khayat D (2010) Treatment for metastatic malignant melanoma: old drugs and new strategies. Crit Rev Oncol Hematol 74: 27-39.

Munoz-Alonso MJ, Alvarez E, Guillen-Navarro MJ, Pollan M, Aviles P, Galmarini CM, Munoz A (2013) c-Jun N-terminal kinase phosphorylation is a biomarker of plitidepsin activity. Mar Drugs 11: 1677-1692.

Munoz-Alonso MJ, Gonzalez-Santiago L, Martinez T, Losada A, Galmarini CM, Munoz A (2009) The mechanism of action of plitidepsin. Curr Opin Investig Drugs 10: 536-542.

Munzone E, Testori A, Minchella I, Mosconi M, Passoni C, Verri E, Cossu Rocca M, Lambiase A, Goldhirsch A, Nolè F (2007) A phase II trial of dacarbazine (DTIC) and bevacizumab in patients with metastatic melanoma. J Clin Oncol 25: Abstract 8579.

Neuman HB, Patel A, Ishill N, Hanlon C, Brady MS, Halpern AC, Houghton A, Coit DG (2008) A single-institution validation of the AJCC staging system for stage IV melanoma. Ann Surg Oncol 15: 2034-2041.

Patel PM, Suciu S, Mortier L, Kruit WH, Robert C, Schadendorf D, Trefzer U, Punt CJ, Dummer R, Davidson N, Becker J, Conry R, Thompson JA, Hwu WJ, Engelen K, Agarwala SS, Keilholz U, Eggermont AM, Spatz A (2011) Extended schedule, escalated dose temozolomide versus dacarbazine in stage IV melanoma: final results of a randomised phase III study (EORTC 18032). Eur J Cancer 47: 1476-1483.

Robert C, Thomas L, Bondarenko I, O'Day S, M D JW, Garbe C, Lebbe C, Baurain JF, Testori A, Grob JJ, Davidson N, Richards J, Maio M, Hauschild A, Miller Jr WH, Gascon P, Lotem M, Harmankaya K,
Ibrahim R, Francis S, Chen TT, Humphrey R, Hoos A, Wolchok JD (2011) Ipilimumab plus dacarbazine for previously untreated metastatic melanoma. N Engl J Med 364: 2517-2526.

Schadendorf D, Ugurel S, Schuler-Thurner B, Nestle FO, Enk A, Brocker EB, Grabbe S, Rittgen W, Edler L, Sucker A, Zimpfer-Rechner C, Berger T, Kamarashev J, Burg G, Jonuleit H, Tuttenberg A, Becker JC, Keikavoussi P, Kampgen E, Schuler G (2006) Dacarbazine (DTIC) versus vaccination with autologous peptide-pulsed dendritic cells (DC) in first-line treatment of patients with metastatic melanoma: a randomized phase III trial of the DC study group of the DeCOG. Ann Oncol 17: 563-570.

Stein MN, Ribrag V, Gomez-Roca CA, Salles GA, Carella AM, Gyan E, Szyldergemajn SA, Kahatt CM, Luque M, Extremera S, De Miguel B, Fernandez-Garcia E, Soria JC (2012) Phase Ib study of plitidepsin (APL) with gemcitabine (GEM) in refractory solid tumors and lymphoma patients. J Clin Oncol 30: Abstract 2539.

Therasse P, Arbuck SG, Eisenhauer EA, Wanders J, Kaplan RS, Rubinstein L, Verweij J, Van Glabbeke M, van Oosterom AT, Christian MC, Gwyther SG (2000) New guidelines to evaluate the response to treatment in solid tumors. European Organization for Research and Treatment of Cancer, National Cancer Institute of the United States, National Cancer Institute of Canada. J Natl Cancer Inst 92: 205-216.

This work is published under the standard license to publish agreement. After 12 months the work will become freely available and the license terms will switch to a Creative Commons AttributionNonCommercial-Share Alike 3.0 Unported License. 